\title{
The Phenomenon of Political Power in Ukraine
}

\author{
By Sergiy Bereziuk ${ }^{1}$, Lyudmila Pronko ${ }^{1}$, Oksana Samborska $^{1}$
}

\begin{abstract}
Political power is the integral part of constituent of development and stability of society, that is why her efficiency are one of main tasks of domestic politics. Success of the state depends in the international political arena, first of all, from experience and professionalism of own political management. Studies of scientists from the marked theme full have not fully covered the of problems, it is today necessary to work out the own effective model of politics, that would connect success and experience of international association, Ukrainian history, traditions and customs. Main reason of the crisis phenomena in Ukrainian society see in absence of clear strategy of development and absence of professional competenses of politicians, in relation to state creation. The purpose of the study is to find out the essence of political power and influence on the effectiveness of statebuilding, substantiation of directions of increasing the effectiveness of political power in Ukraine on the basis of political intelligence.
\end{abstract}

Keywords: state, politics, development, post-soviet countries, reform, president

\section{Introduction}

Generally speaking, power does not spoil people, but fools, when in power, corrupt power.

(Bernard Shaw, 2016...)

For period of independence of Ukraine, looked after many failure reforms that tighted a country in debitors before investors, and also and economic flights that helped to level a situation on the best. Among the most ponderable successes it costs to mark money reform, entering to WTO, signing of political part of agreement about an association between Ukraine and countries of of the European Union, signing of agreement about the visa-free mode with the countries of the European union. The basic failures of politics of our presidents and governments resulted in a volume, that a country is an outsider on the indexes of developmentT and stability of economy among the countries-members of the European Union and former post-soviet countries. It properly influences on her investment attractiveness and political situation on the whole, in fact socio-political tension is conditioned first of all by the considerable slump of economy and reduction of workplaces, parity prices, by growing unemployment and migration of skilled labour force abroad.

It costs to mark that Ukraine among leaders after the level of corruption that occupies the first place on the version of EY Fraud Surveys. The Human Development Index and quality of life, unlike the economic rating in a country stipulated falling of positions of Ukraine that occupies 132 places in rating between Ghana and Uganda. Human 
development index Ukraine occupies 84 places in rating 187 countries. Such index however allowed to the country to get in higher category of human development. Ukraine retains stable positions of Human development index - 0,747 in 2015 and 0,7512018 (Samborska, 2019...).

According to the ratings of the development of the political and legal environment, Ukraine has improved its positions - it is in the top 50 in the ranking of army capacity, however, in other indexes - Ukraine is lagging behind the ranking. This is due to military developments in eastern Ukraine, annexation of Crimea, political instability, corruption and failed judicial reform. In terms of income, Ukraine's performance was below average - 2 place after Vietnam, beating Mongolia, Moldova, Armenia and India (Ukraine in the global rankings 2017-2018...).

One of the reasons for the ineffective policy of national officials is the divergence of views with the society, the main role of the authorities in the socio-economic development of the country. It is also worth noting the low level of professionalism of officials and the lack of relevant competencies, experience in public administration and government.

\section{Materials and Methodology}

The task is to identify the main reasons for the inefficiency of political power in Ukraine and to develop directions for improving its effectiveness.

General scientific methods of research: analysis and synthesis (study of the effectiveness of the Institute of the Presidency of Ukraine) were used to write the article; monograph (analysis of the effectiveness of government policy and presidents of Ukraine); comparative analysis (comparison of GDP per capita in Ukraine and countries of the world); abstract-logical (generalization and formation of conclusions); a dialectical method of cognition (all phenomena and processes are explored in relation, interdependence and historical development).

\section{Research}

Historically, the development of mankind has always been associated with the establishment of the power that set the vector of development. The first manifestations of power date back to the primitive community. At the time, power was primitive, though it had integral components - power and leadership. Today, political power, which embodies the achievements of mankind and receives the challenges of today, should promote the development of a democratic, humane, developed society on a planetary scale for the continued existence and development of mankind. With independence, the citizens of Ukraine have optimistically plunged into a period of economic transformation. The main goal was envisaged the socio-economic development of the country with a powerful industrial complex, a large segment of the service sector and efficient state-building.

The «Main directions of economic policy of Ukraine in the conditions of independence», approved by the Verkhovna Rada on 25 October 1991, stated: «A radical restructuring of the national economy, dramatic changes in investment activity are considered as the 
most important priorities of economic development for giving it more dynamism and social orientation» (Moldovan, 2011...). This statutory instrument of twenty years ago shows that politicians of that time had a clear understanding of the strategic for reform. Twenty-eight years ago, it can be stated that not all directions were fully realized, and some of them even regressed in comparison with the upward indicators - Ukraine partially lost production potential formed during the Soviet Union, without taking any steps in the direction of modernization. economy.

The reasons for the enormous backwardness of Ukraine's economy from other postSoviet states lie in miscalculations of state policy, lack of experience of independent economic development, dogmatic implementation of the International Monetary Fund (IMF) advice on economic transformation, difficult geopolitical and geoeconomic location of the country.

Since Ukraine's independence, the number of candidates for the presidency has grown rapidly. Thus, in 1991 there were 6 candidates, in 2019 - 44, 24 were in 2004, the «Orange Revolution» and 21 in 2014 were the «Dignity Revolution» (Fig. 1).
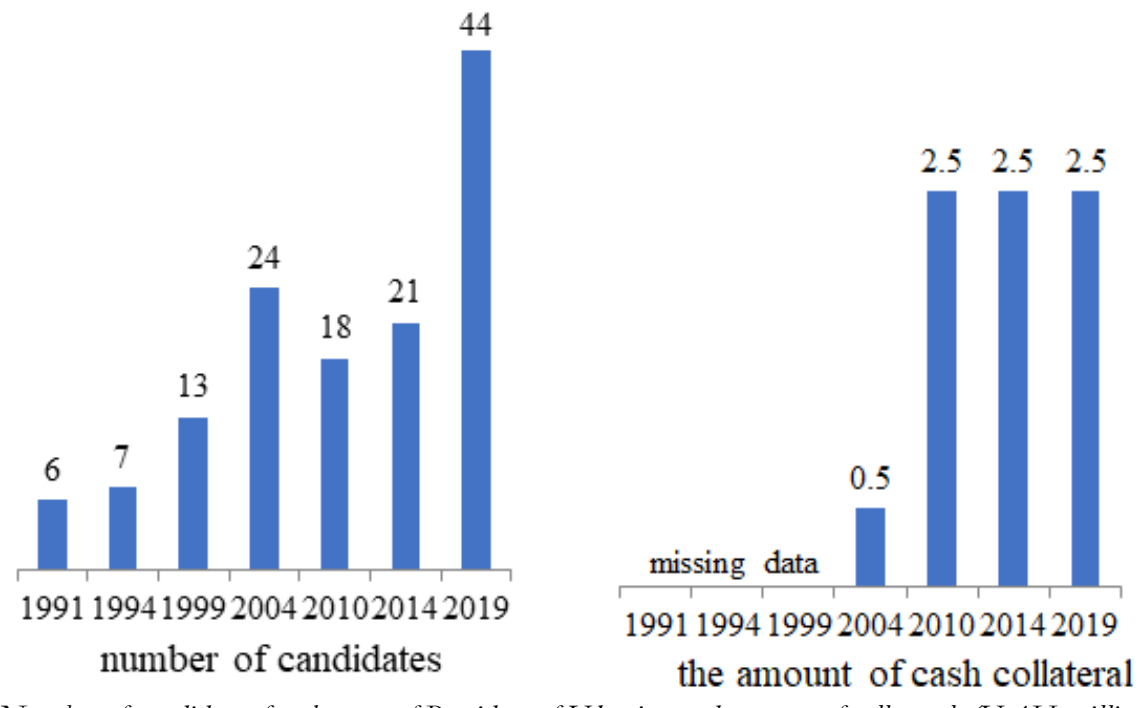

Fig. 1. Number of candidates for the post of President of Ukraine and amount of collateral, (UAH million)

It is worth noting that the smallest number of candidates for the post of President of Ukraine was observed in the period 1991-1999. Starting from 2004 the collateral amounted to UAH 0.5 million - 24 candidates) to 2019 inclusive (the collateral amounted to UAH 2.5 million - 44 candidates), the number of candidates increased and the amount of the collateral accordingly. It is quite the opposite tendency - the growth of the pledge of money for participation in the elections seems to «generate» a large number of candidates, most of them men. It is paradoxical that the cadence of each president of Ukraine was characterized by a high rating at the beginning of the cadence and a significant decline in the rating at the end (Fig. 2). 


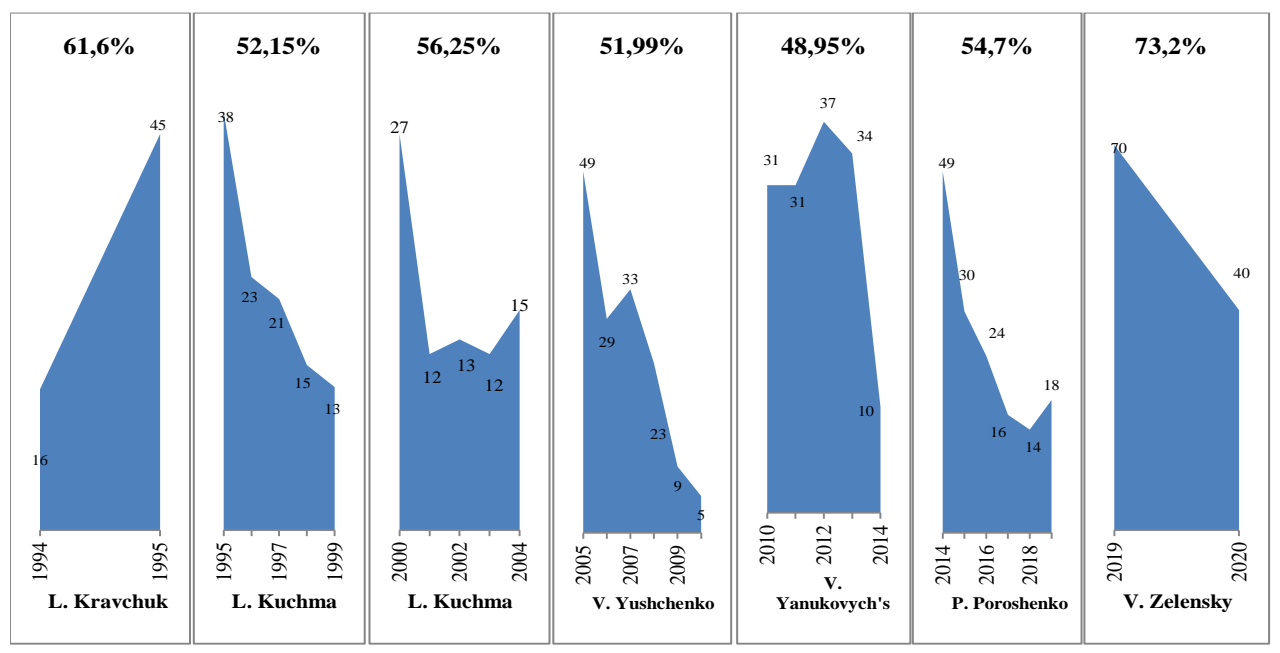

Figure 2. The level of trust in the presidents of Ukraine

Source: ( Trust ratings of the presidents of Ukraine, 2019...),

(*An unstable Ukrainian government scares investors away. 2019)

The first president of Ukraine, L. Kravchuk, won $61.6 \%$, but by the end of the term, only $16 \%$ of Ukrainians supported his ideas. Kuchma won the presidential election twice, garnering more than $52 \%$ of the vote, but at the end of the first and second term, his ratings dropped substantially to $13 \%$.

In 2005, Yushchenko supported the presidential election - 52\% of Ukrainians, and in 2009 - only 9\% of the electorate.

V. Yanukovych's rating during his term of office had significant growth periods, but in 2014, due to the change in the vector of the country's integration processes, the president's rating decreased to $10 \%$.

The fifth president of Ukraine, P. Poroshenko, supported some 55\% of the electorate, but in 2019 , only $19 \%$ of the electorate.

The sixth president of Ukraine in 2019 elected V. Zelensky, who won with a result of $73 \%$ of the vote. According to the results of the president's work, within 100 days, $70 \%$ of the respondents trust him.

The result of the work of the president and his team is an indicator of the effectiveness of the country's development, that is, Gross Domestic Product (GDP) growth (Figure 3). 


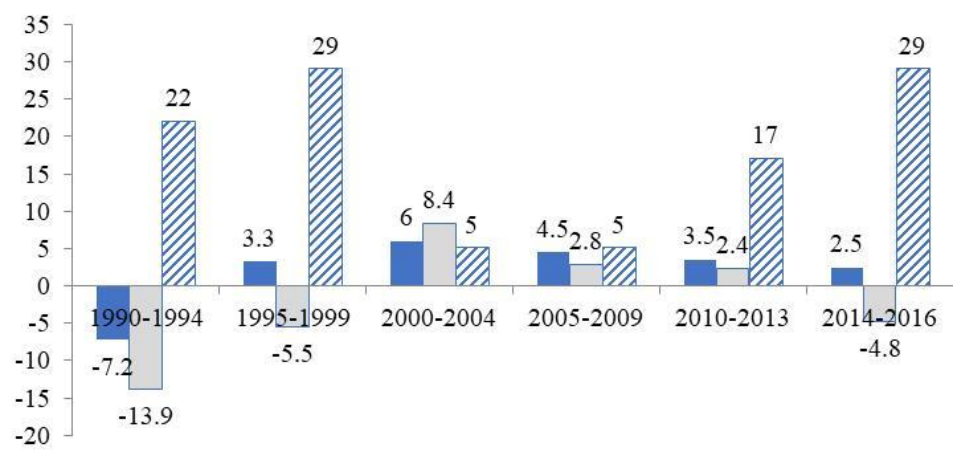

- post-socialist countries
$\square$ Ukraine
¿Ukraine's place in the ranking among post-socialist countries

Fig. 3. Average annual Gross Domestic Product growth rates of Ukeraine against post-socialist countries in 19902016, $(\%)$

The actions of President L. Kuchma for the economy were dynamic in terms of overcoming the crisis, implementing reforms and ensuring the growth of the Ukrainian economy. For the period 2000-2004, the country's average GDP increased by 8.4\% per year, securing the fifth place among post-socialist countries. During the same period, the President adopted about 400 decrees for the prompt resolution of economic problems, overcoming the crisis and implementation of reforms, due to which the country has made dynamic changes in the economy there was a fall in the crisis [6].

However, in 2009 Ukraine was again in economic crisis, the country's GDP declined $14.8 \%$, which was the worst indicator among post-socialist countries, which shows that the authorities could not find ways to overcome the global crisis. In 2014-2015, with the country's GDP declining at $16.4 \%$ (Figure 4), there was a domestic crisis caused by Russian aggression and war, as well as the government's wrongful reaction to the situation.

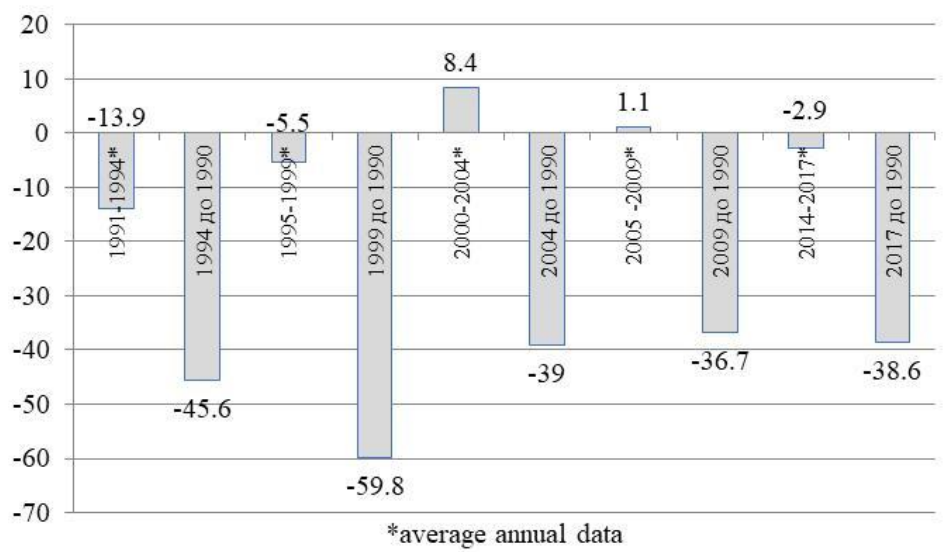

Fig. 4. Gross Domestic Product dynamics of the country 1991-2017,\% 
The economic performance of the presidents of Ukraine is appropriately perceived by citizens. Surveys and polls show that Leonid Kuchma believes that the best policy is considered to be the best policy by the public on the economic performance of the presidents, reaching 29.1\% (Fig. 5).

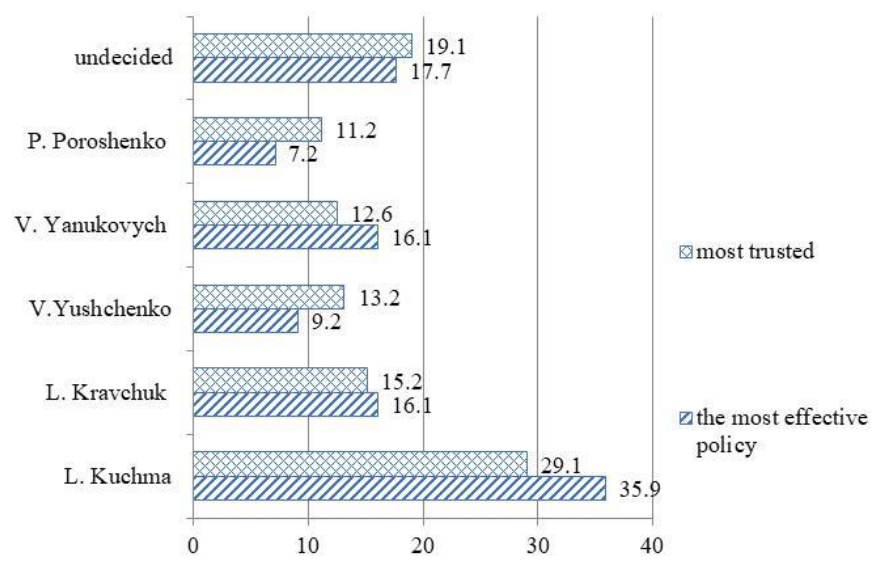

Fig. 5. Level of trust of citizens to the presidents of Ukraine, \%

Source: (Trust ratings of the presidents of Ukraine. 2019....)

According to the polls of Ukrainians, the least effective policy was conducted among the presidents of P. Poroshenko, the level of confidence was $7.2 \%$, while the country's administration under L. Kravchuk and V. Yanukovych was estimated equally about 16\%. According to the survey, $60 \%$ of the respondents consider the policy of President V. Yanukovych unsatisfactory, blamed for the low socio-economic development of the country, P. Poroshenko - 53\%, V. Groysman - 40\%, Azarov - 51\% (Fig. 6).

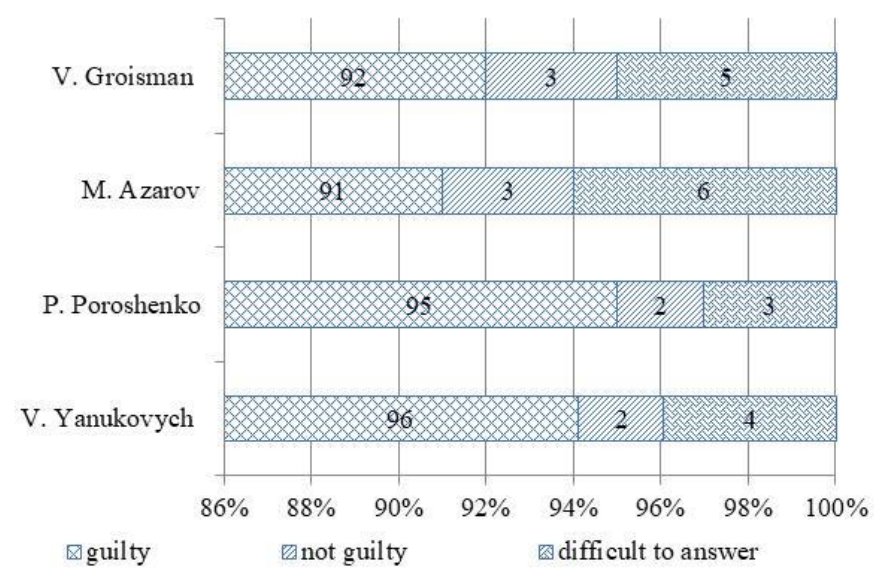

Figure 6. Responsibility of citizens for the state of the economy of Ukraine from the point of view of citizens in the period of cadence, $\%$

Source:(Presidential Election - 2019...) 
Signs of political intelligence are integrity, impartiality, the ability to curb personal managerial ambitions, procrastination by the authorities [8]. The professional way of thinking is the ability to deal with ambiguous situations, to understand the role and importance of any sphere - public, business, non-profit sector, to be able to adapt, to respect values (Lyashenko. Political intelligence syndrome. 2019...).

According to O. Lyashenko, the main features of the Ukrainian «syndrome of political intelligence» are the conscious or unconscious interruption of the natural connection of generations, some encapsulation, fragmentation / fragmentation, not systematic, tacticalcentric, unprofessional (Lyashenko. Political intelligence syndrome. 2019...) Considers political intelligence as a combination of the ability to see and understand the political landscape with the ability to «maneuven» political minefields. In her opinion, the presidents of Ukraine have a certain age-old «move»:

- the first presidents L. Kravchuk and L. Kuchma belong to the silent generation;

- V. Yushchenko and V. Yanukovych belong to the baby-boomer generation;

- O. Turchynov (acting President for 104 days), P. Poroshenko are representatives of the early days of Generation X;

- V. Zelensky is on the front between the late «X» and the very early «Y»; this is the term «State in the smartphone» (Lyashenko. Political intelligence syndrome. 2019...)

Thus, all presidents are almost typical representatives of their generations, however, each of them has and has «symptoms of political intelligence».It should be noted that the intelligence quotient (IQ - intelligence quotient) is a quantitative assessment of the level of human intelligence, the level of intelligence relative to the level of intelligence of the average person of the same age. Most researchers believe that overall, the average development of intelligence is about the same in men and women. At the same time, men with very high or very low intellect prevail (Intelligence...). It is worth noting that the majority of men in the Ukrainian Parliament, but the results of the adopted legislative acts of the Verkhovna Rada of Ukraine, unfortunately, raise many additional questions about the expediency of these laws. In general, the situation in the world is not better, a small percentage of the population with high level of intelligence follow (fig.7).

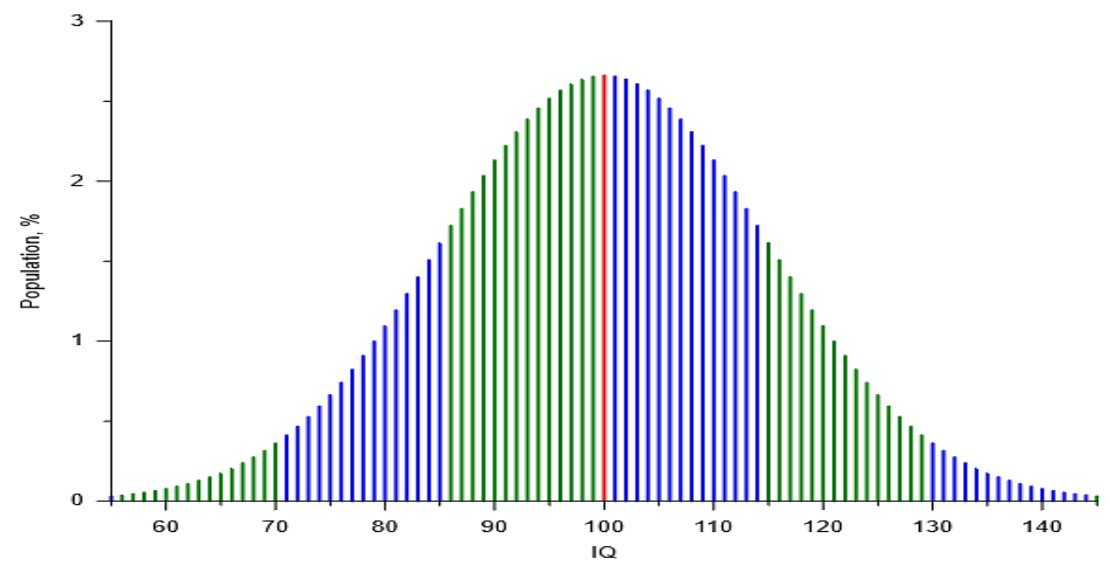

Figure 7. Structure of the world's population by level of intelligence

Source: [10] 
At the same time, not everyone sees a link between IQ levels and a person's mental capacity. According to Scientific American, there are three main views on the relationship between IQ and success in the «Oval Office»:

$\checkmark$ The smarter the president, the better;

$\checkmark$ You only need to be smart to succeed as president;

$\checkmark$ Someone may actually be too smart for the presidency (Presidential Election 2019...)

Theodore Roosevelt, known as the 26th President of the United States with an indicative IQ of 142,275, believed that «the government has the right and responsibility to regulate big business so that its actions do not adversely affect the general public».

Ulysses Simpson Grant The 18th US President has an IQ score of 120 points, considered one of the «unwise», at the same time he became a national hero and won the title of victorious Commander-in-Chief of the Union Army during the Civil War. (Presidential Election - 2019...).

The presidents of Ukraine have remembered important strategic decisions, signed agreements, loud statements, failures and curious situations. Table 1 outlines the most important geopolitical decisions of our presidents that have influenced the development of national politics and statehood.

Table 1. The most important geopolitical decisions of the Presidents of Ukraine

\begin{tabular}{|c|c|}
\hline Presidents & Decision making \\
\hline L. Kravchuk & $\begin{array}{l}\text { December 7-8, } 1991 \text { - signed the Belovezh Agreement on the Elimination of the } \\
\text { USSR and the Creation of the Commonwealth of Independent States (CIS); } \\
\text { - June 14, } 1994 \text { - signed the Cooperation and Partnership Agreement with the } \\
\text { European Union, which laid the foundation for Ukraine's European integration. }\end{array}$ \\
\hline L. Kuchma & $\begin{array}{l}\text { December } 1994 \text { - signed the Budapest Memorandum on Ukraine's refusal of } \\
\text { nuclear weapons in exchange for guarantees of sovereignty on the part of the } \\
\text { United States, Great Britain and Russia; } \\
\text { - } 1997 \text { - signed the Charter on Special Partnership between Ukraine and NATO; } \\
\text { - signed a Black Sea Fleet Sharing Agreement with Russia, under which Russian } \\
\text { troops were to leave Crimea in } 2017 \text {. } \\
\text { - } 2002 \text { signed the NATO-Ukraine Action Plan, which set out Ukraine's aspirations } \\
\text { for NATO membership; } \\
\text { - 2003, at the insistence of the President, the country's aspirations for Eoropean } \\
\text { Union and NATO membership were reinforced; } \\
\text { - signed an agreement on creation of the Common Economic Space with Russia, } \\
\text { Belarus and Kazakhstan. Ukraine has not developed its participation in this project; } \\
\text { - January } 2004 \text { agreement between Ukraine and the Russian Federation on the } \\
\text { Ukrainian-Russian state border. }\end{array}$ \\
\hline $\begin{array}{l}\text { V. } \\
\text { Yushchenko }\end{array}$ & $\begin{array}{l}2007 \text { Negotiations begin to replace the Partnership and Cooperation Agreement } \\
\text { with the EU with a new enhanced format for cooperation - the Association } \\
\text { Agreement with the European Union; } \\
\text { - } 2008 \text { was the year of receipt of the NATO Membership Action Plan and was a } \\
\text { step up this summer; } \\
\text { - an attempt to obtain a tomos about the autocephaly of the Ukrainian church, } \\
\text { which was not successful; } \\
\text { - started a dialogue with the EU on Ukraine getting a visa-free regime. }\end{array}$ \\
\hline
\end{tabular}




\begin{tabular}{|l|l|}
\hline Presidents & Decision making \\
\hline V. & $\begin{array}{l}2010 \text { concluded the Kharkiv Agreements with Russia on the extension of the } \\
\text { Russian Black Sea Fleet's stay in Crimea from } 2017 \text { to } 2042 \text { in exchange for a } \\
\text { discount on gas; } \\
\text { - for legislative initiatives, removed the mention of Ukraine's desire to integrate } \\
\text { into NATO and added a rule on Ukraine's non-aligned status; } \\
\text { - refusal to sign the Association Agreement with the EU. This decision led to } \\
\text { protests in Kiev, which were later called Euromaidan; } \\
\text { - In March 2014, he wrote a letter to Russian President V. Putin regarding the use } \\
\text { of armed forces in Ukraine to restore «peace, law and order». }\end{array}$ \\
\hline $\begin{array}{l}\text { P. } \\
\text { Poroshenko }\end{array}$ & $\begin{array}{l}\text { signed Minsk agreements to stop active fighting in Donbass; } \\
\text { - signed the Association Agreement with the EU, and under his presidency Ukraine } \\
\text { fulfilled the requirements for obtaining a visa-free regime, and it entered into force; } \\
- \text { on its initiative, Ukraine terminated the Agreement on Friendship and } \\
\text { Cooperation with Russia. } \\
\text { - initiated the consolidation in the Constitution of Ukraine of the course of } \\
\text { accession to NATO and the Europen Union; } \\
- \text { lobbied for the creation of a local Orthodox church independent of Moscow and } \\
\text { the receipt of a volume of autocephaly from the Ecumenical Patriarch in Ukraine. }\end{array}$ \\
\hline
\end{tabular}

Source: (Nowatsky...)

Thus, political power indicates the basic vector of economic development of the country and society. During the period of independence, Ukraine has been declining, an outsider among post-soviet and EU countries in terms of economic development. The severing of economic and trade ties has, in fact, led the country's economy to decline and impoverishment. This is evidenced by the fact that the minimum wage of a Ukrainian is 12 times lower than the wage in the countries of the European Union (The minimum wage in Ukraine is 9-12 times lower than in the richest EU countries...).

In our view, one of the reasons is the instability of political power, which is why the incompleteness of political reforms and, as a consequence, the uncertainty of investors in the future of their own investments. Our politicum can be characterized as unstable and its actions ineffective and inactive.

In the period from 1992-2019, 20 Prime Ministers have changed in Ukraine, each working an average of 1 year 4 months (Fig. 8). The same number of leaders has changed in Poland, Lithuania, Romania, with the performance of their Governments gradually increasing. The lowest number of heads of government is observed in Belarus - 9 people, the indicators of GDP development of the country have steadily increased approximately 4 times since 1992. 


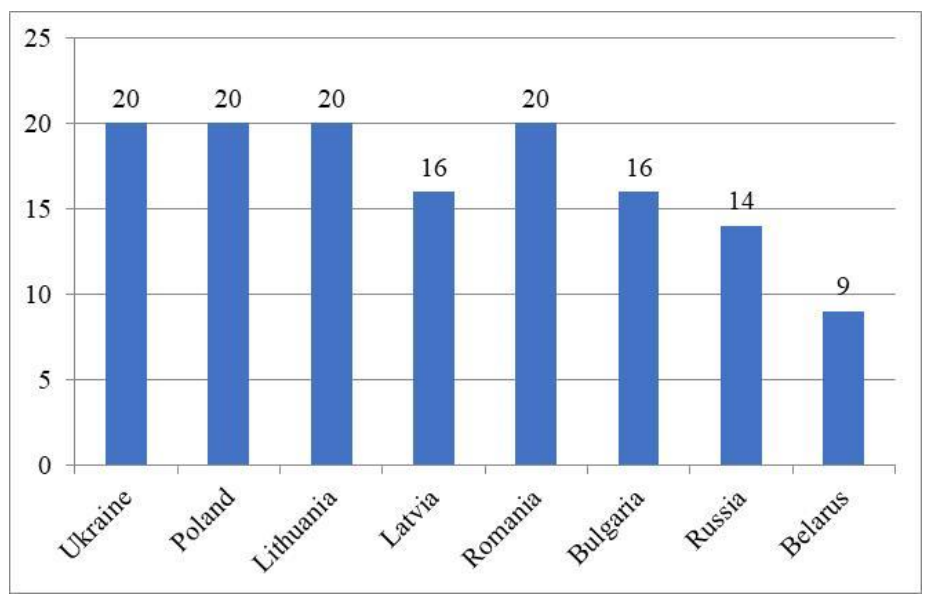

Fig. 8. Number of heads of government in different countries 1992-2019, persons

Source: (Wikipedia...)

The instability of political power and its incompetence affected GDP per capita (Fig. 9). Analyzing, it should be noted that, after almost identical conditions in 1991, a number of post-socialist countries have different results of activity. The highest indicators of economic development are observed in the Baltic States in the amount of 35 thousand dollar, above, is GDP in Lithuania and Latvia. In Poland, gross domestic product grew by 30\% over the period 2015-2019 to \$32 thousand dollar. At the level of 30 thousand dollar. The US indicator of development was in the Russian Federation, and 28 thousand dollar in Bulgaria.

Ukraine, per capita, has the lowest rate for the analyzed period, almost unchanged, reaching \$10,000 in 2019 dollar USA. These results are primarily indicative of the ineffective economic policies of the Presidents and the Government.

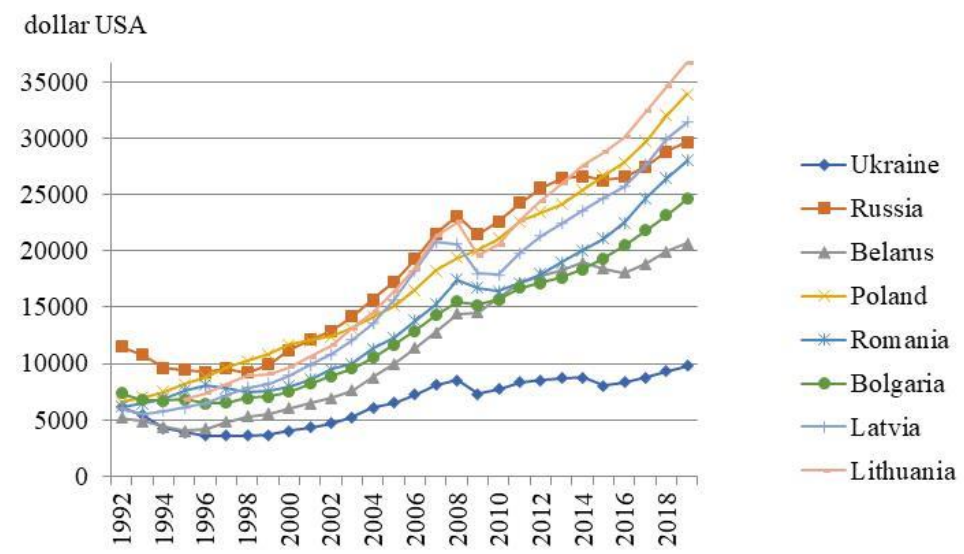

Year...

Figure 9. Gross domestic product per capita 1992-2019 (in post-socialist countries), current prices Source: (World Economic Outlook (WEO), October 2019) 
Foreign direct investment in Ukraine is decreasing. The latest investment was \$2.4 billion in 2018, down 10\% from the previous year. Kazakhstan has higher foreign investment rates. Observing the economic downturn in 2019 in Ukraine, according to recent observations, Ukraine's debt load has fallen from 80\% of GDP in 2016 to 52\% today, with inflation at about 4\%. Interest rates have fallen by about 700 basis points over the past few years to $11 \%$. Ukraine's economy is volatile, with GDP growing $0.1 \%$ in the fourth quarter, decelerating from $0.6 \%$ in the third quarter, the slowest growth since 2016. In 2019, Ukraine's economy grew by 1.5\%, better than in Russia, but below market forecasts by $2.3 \%$ of European Union countries. Ensuring macroeconomic stability and stimulating foreign direct investment should be the top priorities of the new government, says Andy Hunder, President of the American Chamber of Commerce in Ukraine.

In our opinion, one of the reasons for the accelerated growth of the economy of these countries is the stability of political power, the gradualness of the reforms and the constant vector of trade and economic relations that cannot be said about Ukraine. Frequent structural shifts in Ukraine's economy from «pro-Western» to «pro-Western» in the eyes of the world community shapes the negative image of Ukrainian power-makers, affecting trust and relationships with partner countries, and leads to increased social tensions within the country itself. We believe that the reason for the failed economic reforms is the lack of policy makers experience in governance, public administration competencies, and state-building.

One of the ways of overcoming the crisis of political power in Ukraine is the improvement of qualification, professionalism of People's Deputies, members of the government and the President's team.

The Constitution of Ukraine provides: «A citizen of Ukraine who has attained thirty-five years of age, has the right to vote, has resided in Ukraine for the last ten years before election day and is fluent in the national language may be elected President of Ukraine. The same person may not be President of Ukraine for more than two consecutive terms» (The Constitution of Ukraine, 1996...). According to the Law of Ukraine «On Elections of People's Deputies of Ukraine», a citizen of Ukraine who on the election day has reached twenty-one years, has the right to vote and has resided in Ukraine for the last five years, may be elected (Law of Ukraine. About elections of People's Deputies of Ukraine...)

As we can see, there are no requirements for intelligence and professionalism, such categories as honesty and honesty are generally offset.

In our opinion, one of the first steps to improve the Ukrainian politicum is to establish a certain minimum of knowledge for politicians of all levels. We also believe that honest professionals with relevant knowledge and experience in government should go to the authorities.

Analyzing the national political intellect, it should be noted that important decisions of the state leadership are not always made on the basis of strategic development and consistent realization of national interests of the country (Lyashenko,2019...).

Today, the global, but not recognized world, is the problem of the gradual decline of the intellectual level of man, as Naked Science notes, «humankind is dumbing down». The Ragnar Frisch Center for Economic Research (Norway) has made the assumption ten 
years ago that in one generation the intellectual level drops by 7 points on average. The reasons scientists call environmental problems, lifestyle change, computer technology.

\section{Conclusions and Proposals}

Political power is decisive for the development of society because it sets the basic vector of its movement. Today, Ukrainian society is going through a deep political crisis caused by the unprofessionalism and myopia of the domestic political party. With a powerful resource potential, the government is unable to use it rationally and develop its own state and make it competitive in the eyes of the world community. As a result, during the period of independence, we can observe the decline of the economy, inflation, the outflow of skilled labor, the destruction of the rural community.

The main reason for the crisis in Ukrainian society is the lack of a clear development strategy that should be passed from government to government. Frequent change of governments, re-election of people's deputies led to the lack of understanding of what to do and how to do it. The difficult situation in politics and the economy is exacerbated by the lack of competence of the Ukrainian politics.

In our view, changes in national legislation are needed to ensure that the Ukrainian people are protected by casual populist politicians who lack any experience of public administration and government. It will allow to supplement the management bodies of specialists, with high level of intellectual development, high of Human development index (HDI), that will be able to lead Ukraine out of political and economic crisis by making it investment, innovative attractive.

\section{Reference}

Bernard Shaw. A genius with an eloquent name. Dr. Nemo, Radio Lemberg, September 4, 2016. (in Ukrainian)

Law of Ukraine. About elections of People's Deputies of Ukraine. URL: https://zakon.rada.gov.ua/laws/show/4061-17

Infographics. 2019 Presidential Election: A record 44 candidates registered. URL: https: //vchasnoua.com/donbass/59535-infohrafika-vybory-prezydenta-2019-dlia-uchasti-ofitsiinozareiestruvalysia-rekordni-44-kandydaty.

Intelligence. URL: https://en.wikipedia.org/wiki/Intelligence\#/media/ File: IQ_ curve.svg.

The Constitution of Ukraine. Chapter V. President of Ukraine. URL: www.president.gov.ua >constitution> constituciya-ukrayini-rozdil-v.

Moldovan O. Twenty years of reform and chaos. Ukrainian Pravda. URL: https: //www. thoughda.com.ua/publications/2011/08/15/294948.

Trust ratings of the presidents of Ukraine. URL: https: //www.slovoidilo.ua/2019/11/08/infografika/polityka/rejtynhy-doviry-prezydentiv-ukrayiny.

URL: https: //dt.ua/ECONOMICS/u-2000-2004-vvp-ukrayini-zrostav-v-serednomu-na-8-4-v-rik-av-20142017-padav-na- 4-8-285417_.html.

Presidential Election - 2019. URL: https: //censor.net.ua/news/3073542/timoshenko_gritsenko_boyiko _zelenskiyi_pervaya_chetverka_oprosa_poroshenko_sedmoyi_agentstvo_reyiting.

O. Lyashenko. Political Intelligence in Ukrainian. URL: https: //www.pravda.com.ua/columns/2019/10/28 /7230280/.

O. Lyashenko. Political intelligence syndrome. URL: https: //www.pravda.com.ua/columns/2019/10/22 /7229739/. 
B. Nowatsky. Five presidents of Ukraine: what they remember. URL: https: //nv.ua/eng/ukraine/politics/p-yat-presidentiv-ukraini-chim-voni-zapam-yatalis-50022632.html.

The minimum wage in Ukraine is 9-12 times lower than in the richest EU countries. URL: https://www.rbc.ua/eng/news/minimalnaya-zarplata-ukraine-9-12-raz-menshe-1580810440.html.

The Prime Minister of Ukraine. From Wikipedia, the free encyclopedia URL: https://en.wikipedia.org/wiki/ $\% \mathrm{D} 0 \% \mathrm{BD} \% \mathrm{D} 0 \% \mathrm{~B} 8$.

Economy of Ukraine. From Wikipedia, the free encyclopedia URL: https: //wikipedia.org/wiki/ $\% \mathrm{D} 1 \% 80 \% \mathrm{D} 0 \% \mathrm{~B} 0 \% \mathrm{D} 0 \% \mathrm{~B} 8 \% \mathrm{D} 0 \% \mathrm{BD} \% \mathrm{D} 1 \% 8 \mathrm{~B}$.

O. Lyashenko. Designing Political Intelligence: From Shrapnel to Victory. URL: https://www.pravda.com.ua/columns/2019/11/11/7231517/.

https://en.wikipedia.org/wiki/\%D0\%A3\%D0\%BA\%D1\%80\%D0\%B0\%D1\%97\%D0\%BD $\%$ D0 $\% \mathrm{~B} 0$.

Samborska O.Y. Human capital as a factor of economic growth of Ukraine. APK economy. International scientific and production journal. Kiev. No. 6.2019.C 64-72.

Ukraine in the global rankings 2017-2018. URL: https://www.uifuture.org/post/ukraina-u-global-ratingah2017-2018/.

World Economic Outlook (WEO), October 2019. URL: https://knoema.ru/IMFWEO2019Oct/imf-worldeconomic-outlook-weo-october-2019\#.

https://gazeta.ua/articles/poglyad/_nestijkij-ukrayinskij-uryad-vidlyakuye-investoriv/957429 